- Structured exchanges of ideas and dissemination of information on funding practice, administration, governance, and corporate community investment;

- Reinforcement of the infrastructure of citizens' associations by the establishment of training, research, and self-help, programmes and facilities to underpin and stimulate organized independent funding; and

- Respect for openness and accountability within the rule of law.

By providing resources and undertaking operational projects, independent funders promote innovation, flexibility, diversity, and voluntary citizen involvement. They have a proven ability to reach out to disadvantaged, minority, and marginalized, groups. They make a key contribution to the creation of open, democratic society and provide both the means and the motivation for active and compassionate citizenship.

To ensure a dynamic and accountable independent funding sector free from narrow national or other interests, the European Foundation Centre therefore calls on governments and European and international institutions to take all appropriate action to:

- Uphold the right of citizens to form new foundations and associations;

- Acknowledge a strong independent sector as an essential component of open civil society;

- Encourage individual and corporate community involvement; and

- Promote funding partnerships between the public, private, and voluntary, sectors.

\title{
Courses on Life-zone Ecology and Tropical Dendrology Offered by the Tropical Science Center, San José, Costa Rica
}

\begin{abstract}
Classification of the Earth's ecosystems and ecocomplexes affects many aspects of both ecological and geographical sciences. Additionally, the identification of plants is closely related to the classification of ecosystems which on land are largely characterized by their plant components. From an academic perspective both subjects are crucial, as they form the basis for sustainable resource management and biodiversity preservation.

Dr L.R. Holdridge's Life-zone Ecology classification system and Tropical Dendrology (a system to identify forest trees) have been used by scientists and other professionals in the tropics for more than 30 years. Furthermore, based on the Life-zone Ecology system, several practical, sound applications have been developed by the Tropical Science Center to be used in rural development, sustainable resource management, watershed management, land-use capability, assessment of environmental impact, territorial zoning, and ecosystem characterization in protected areas.

Recently, the United States National Atmospheric and Space Agency (NASA) prepared an earth map of life-zone ecosystems which has been used to monitor and predict vegetation changes due to the increase in atmospheric $\mathrm{CO}_{2}$ (the so-called 'greenhouse effect'). Also, in 1992, the World Conservation Monitoring Centre (WCMC), located in Cambridge, England, gave strong support to the Holdridge Life-zone system by including it in their official publication 'Global Biodiversity: Status of Earth's Living Resources'.
\end{abstract}

\section{Bay of Bengal Islands' Population and Environment Future: An Urgent Appeal}

$T^{\text {h }}$ he Andaman and Nicobar Islands are situated in the Bay of Bengal, have a total geographical area of 8,294 sq. $\mathrm{km}$, are bestowed with one of the world's richest ecocomplexes of forest, marine, and mangrove, maintaining partly- or completely-closed systems of energy, nutrients, and fresh water. These Islands harbour an irreplaceable gene-pool of many interesting endemic plants and animals, unique to the islands and confined to some specified areas representing Indo-Chinese and IndoMalayan elements.

The ecology of the Andaman and Nicobar Islands is fragile and very sensitive to population growth. The present human population of about 0.3 million already exceeds the absolute carrying capacity of 0.25 million of
Upon participating in the Life-zone Ecology course, students should have gained enough knowledge to implement sound, practical applications of the system to activities as mentioned in the preceding paragraphs. After attending the Tropical Dendrology course, students should be accomplished at identifying a large proportion of tropical trees and shrubs down to family, genus, and in some cases species. Successful course participants will also gain special skills enabling them to continue making progress on their own upon returning to their respective countries.

Courses last for 3 weeks and will be offered in 1994 from March 21 to April 8 (Dendrology), and from April 25 to May 13 (Ecology). Costs will be US $\$ 2,500$ for Tropical Dendrology and US \$2,700 for Life-zone Ecology (please note that these amounts include accommodation but not airfares). For additional information, please contact the undersigned.

\section{HuMBERTO JiMÉNEZ SAA Tropical Science Center P.O. Box $8-3870$ \\ San José 1000, Costa Rica.}

Tel. (506) 252649

or 533267

Fax (506) 534963 these islands, while the projected population of 0.45 million or even more in $\mathrm{AD} 2000$ is estimated to make annual demands of 442 thousand million litres of water (both drinking- and irrigation-) and 0.9 million tonnes of firewood. Intensive agriculture over $500 \mathrm{sq}$. $\mathrm{km}$ would require 8,500 tonnes of fertilizers and 275 tonnes of pesticides for optimum yield. The consumption of petrochemicals for power and transport would be 50\% more than the present annual consumption of 38 thousand million litres of petrol and 37.5 thousand million litres of high-speed diesel oil.

The ultimate target of the exploding population is to clear virgin forest to meet the requirements of agriculture, firewood, settlements, fodder, etc. - leading to the extinction or threatening of the survival of endemic flora and 